\title{
Implementation and Strengthening of Visible Learning for Elementary School Students' in Indonesia
}

\author{
Sri Buwono ${ }^{1}$, Hadi Wiyono ${ }^{1}$, Jagad Aditya Dewantara ${ }^{2 *}$ \\ ${ }^{1}$ Department of Social Education, Universitas Tanjungpura, Indonesia \\ ${ }^{2}$ Departement of Civic Education, Universitas Tanjungpura, Indonesia \\ *Corresponding email: jagad02@fkip.untan.ac.id
}

Received: 13 April 2021

Accepted: 14 July 2021

Published: 18 August 2021

Abstract: Implementation and Strengthening of Visible Learning for Elementary School Students in Indonesia. Objectives: The purpose of this study is to describe the strengthening of visible learning in basic education students. Methods: This research uses mixed methods, namely quantitative and qualitative methods. The participants were elementary and junior high school teachers in Sanggau Regency, West Kalimantan Province with a total sample of 50 teachers. Data collection techniques using questionnaires and interviews. Analysis of the data using correlation analysis techniques Moment Product and t-test. Findings: The results of the study found that the implementation of six variables, four variables in the very good category and two in the good category. The relationship between variables between $r$ values of 0.470 to 0.808 shows a strong and positive relationship. Interest analysis shows that the overall value of the variables is very important, and the variables that need strengthening are the variables of students, homes and teaching approaches. Conclusion: The implementation of visible learning factors for elementary education students has been implemented well and very well.

Keywords: visible learning, elemenetary school students, mixed method.

Abstrak: Implementasi dan Penguatan Pembelajaran Visibel Pada Peserta Didik Sekolah Dasar di Indonesia. Tujuan: Tujuan penelitian ini untuk mendeskripsikan penguatan pembelajaran visibel pada peserta didik pendidikan dasar. Metode: Penelitian ini menggunakan metode campuran yaitu metode kuantitatif dan kualitatif. Partisipan merupakan guru-guru SD dan SMP di Kabupaten Sanggau Provinsi Kalimantan Barat dengan jumlah sampel sebanyak 50 guru. Teknik pengumpulan data menggunakan angket dan wawancara. Analisis data menggunakan teknik analisis Korelasi Produk Moment dan Uji-t. Temuan: Hasil penelitian menemukan bahwa implementasi dari enam variabel, empat variabel berkategori sangat baik dan dua berkategori baik. Hubungan antar variabel antara nilai r 0,470 sampai 0,808 menunjukkan hubungan yang kuat dan positif. Analisis kepentingan menunjukkan nilai keseluruhan variabel sangat penting, dan variabel yang perlu penguatan yaitu variabel peserta didik, rumah dan pendekatan

pengajaran. Kesimpulan: Implementasi faktor-faktor pembelajaran visibel pada peserta didik Pendidikan Dasar sudah diimplementasikan dengan baik dan sangat baik.

Kata kunci: pembelajaran visibel, siswa sekolah dasar, metode campuran.

\section{To cite this article:}

Buwono, S., Wiyono, H., \& Dewantara, J, A. (2021). Implementation and Strengthening of Visible Learning for Elementary School Students' in Indonesia. Jurnal Pendidikan Progresif, 11(2), 139150. doi: $10.23960 /$ jpp.v11.i2.202101. 


\section{INTRODUCTION}

Efforts to improve learning so that learning activities in the classroom are more effective have been carried out. The increase in knowledge is mainly done by applying various kinds of learning approaches. One of the efforts to increase learning is through visible education, or what is known as visual learning. Visible learning is carried out using students' perspective and students' attitudes who think it is the key to continuous learning (Rømer, 2019). The term visible learning is a concept developed by John Hattie, which summarises 800 meta-analysis results from 50,000 research results that discuss the factors that influence practical learning activities in the classroom. Visible learning introduced by John Hattie, among others, saw that learning objectives were challenging and explicit and accurate, or it could be said that education was visual and meaningful to students (Ivan et al., 2009).

Visible learning is essentially learning that has a visual impact, namely empowering education and continuous learning. Visible learning involves the teacher and sees the effects of learning through the attitudes and behaviour of students. Students understand well the learning objectives as the key to their continuous learning (Raiyn, 2016). Hattie (2008), identify the various factors that support learning to be meaningful and then classify the supporting learning factors into several main factors. The grouping of the main factors for visible learning by John Hattie was then included in six main factors: student factors, home learning environment, school learning environment, teachers as learners, curriculum, and learning approach factors. The six factors are then variables or indicators in implementing how visible learning is applied in schools. From the factors developed by John Hattie, it can be seen that there are factors outside the learning process that also support visible learning, such as the learning environment from home. The house factor is an essential factor that teachers need to pay attention to in realising visual learning (McKnight \& Whitburn, 2020).

Suppose it is connected between the visual learning approach and the learning objectives. In that case, it can be said that visible learning is included in the ideals mandated by the Education System in Indonesia as stated in Law Number 20 of 2003 concerning the National Education System in article 4 paragraph 3 that "Education is organised as a lifelong process of cultivating and empowering students. Likewise with visible learning emphasises the empowerment of students in the learning process. Therefore, visual learning is a supporter of lifelong learning. The concept of lifelong education holds that education does not only take place in schools. Education can occur outside of school in the family environment and the environment of everyday life. Thus, the learning process of students can also learn at school and outside of school. Therefore, strengthening visible learning will occur and by the concept of lifelong Education (Hattie, 2008).

Visible learning is indispensable in realising the principles and ideas of transformation education. Students carry out understanding; they are expected to be what they want. Through lifelong learning, they transform themselves. This principle is in line with the focus of human transformation that humans are autonomous and have various types of potential (Anderson \& Krathwohl, 2010). This potential is then developed so that it becomes the transformation of man himself.

Humans are creatures that grow and develop. The goal is to optimally create the potential to gain a better life by increasing the necessary competencies. Through lifelong learning, Indonesian people strive for their competence to improve their lives. Visible learning is expected to encourage and develop the knowledge, personality, and skills of students. 
Students, either consciously or unconsciously, attempt visual learning so long that education is still ongoing (Qvortrup, 2019).

Through the visual learning paradigm, learning becomes meaningful when teachers use strategies and models that ensure that knowledge is said to be "taking place". The take the place of learning, in this case, is that students feel fully involved when the learning process between teachers and students is carried out. Learning becomes "visible" if the subject curriculum and learning objectives are challenging, explicit, and tangible (Hattie, 2012). The teacher must understand that the learning process to realise meaningful learning for students ensures that all students feel involved in education. The strengthening of visible learning occurs in principle, including the teacher's attitude in understanding the way students perceive learning. Besides, students' philosophy in responding to education is the key to continuous learning. Visible learning can be successful when students know what to do and how to do it (Fisher et al., 2016).

The implementation of the 2013 curriculum in West Kalimantan province has been implemented in all schools. It is recognised that the performance of the 2013 curriculum for each city and district has varied achievements. Still, generally, it can be appropriately implemented depending on several supporting factors for learning. Therefore, the success of good education that empowers students' potential to learn sustainably needs to be considered. The supporting elements for strengthening visible knowledge in students need to be researched through the visual learning paradigm to see how to implement visible learning in schools.

This study seeks to examine the level of implementation of visible learning in schools. This research also tries to focus on the interconnectedness of the factors that support strengthening visible learning. This research was conducted to deepen the direction of learning changes in implementing the 2013 Curriculum in learning. The objectives of this study include 1) To evaluate the linkage of factors driving the strengthening of visible learning that occurs in students to obtain an overview of the changing trends in student learning; 2) Conduct further analysis to obtain an overview of the processes and efforts made by educators so that they can formulate recommendations for strengthening visible learning for students.

\section{METHODS}

The approach used in this study uses a mixed system. A research approach combines quantitative and qualitative methods in one study (Lopez-Fernandez \& Molina-Azorín, 2011; Molina-Azorin, 2016). Quantitative methods are used to obtain clarity on the status of variables or factors that form visible learning. Identifying the roles of variables that make up visual learning facilitates analysis of the relationship between variables. Qualitative methods are used to assess the importance of variables for strengthening efforts to emerge from visible learning. Participants in this study were 29 teachers at the elementary school level and 21 junior high school teachers so that the total number of participants in this study was 50 people.

We are collecting data in this study through direct and indirect data collection methods. The direct approach is carried out by interviews which are conducted using telephone communication. The indirect way is through a questionnaire or questionnaire. The questionnaire was arranged based on the object of research which consisted of 48 question items. The form of the questionnaire was placed in closed questions with the type of ordinal answer choices.

The data analysis technique used to analyze the data questionnaire is to use the Moment product correlation and t-test. Product 
142 | Jurnal Pendidikan Progresif, Vol. 11, No. 2, pp. 139-150, August 2021

Table 1. Visible learning factors

\begin{tabular}{llcc}
\hline No & Factor & Subvariabel & $\begin{array}{c}\text { Statement } \\
\text { Items }\end{array}$ \\
\hline 1 & Students & 6 & 10 \\
2 & Home learning environment & 2 & 6 \\
3 & Learning environment at school & 2 & 4 \\
4 & Teachers as Learners & 8 & 17 \\
5 & Curriculum & 2 & 3 \\
6 & Teaching approach & 5 & 8 \\
\hline & Total & 25 & 48 \\
\hline
\end{tabular}

moment correlation is applied to answer the relationship between visible learning variables. In testing the significance of the relationship between variables, a significance level of $5 \%$ can be used. The significance test uses two sides to answer whether or not there is a relationship between variables. According to the coefficient number and the sign (+/-) of the correlation number, if the correlation number is obtained above 0.5 , it shows a fairly strong relationship between 20 variables and vice versa if the correlation is below 0.5 the correlation is weak. The positive sign $(+)$ indicates the direction of the positive relationship between variables, while the negative number (-) indicates the direction of the negative relationship between variables.

The t-test was conducted to obtain an indication of the efforts that need to be made from each variable that supports visible learning. In testing the t test using a significance level of $5 \%$. The significance test of the $t$ test uses two sides. Meanwhile, the interview data analysis technique is the interactive model analysis in the form of reduction, presentation and conclusion drawing. The collection of research data includes data on research objects in the form of implementing visible learning, linkages of driving factors for strengthening visual education, descriptions of processes, and educators' efforts to design recommendations for improving visible learning for students.

In table 1 , there are six visible learning factors with a total of $25 \mathrm{sub}$-variables and the number of statement items used in the research questionnaire totalling 48 statement items. The six factors of visible learning consist of students, Home study environment, Learning atmosphere at school, Teacher as Learner, Curriculum, and Teaching approach.

\section{RESULTS AND DISCUSSION}

The research results on the implementation and strengthening of visible learning for students in schools are grouped into four parts: Implementation of visual learning, the relationship of variations between the performance of visible education, the importance of visible learning, and strengthening of visible learning in schools.

\section{Implementation of Visible Learning}

To see how the implementation of visible learning in schools is analysed by looking at six supporting factors for learning observed in visual learning, including children's factors as learners, home environmental factors, school environmental factors, teacher/educator factors, curriculum factors, and factors of the teaching approach applied. 


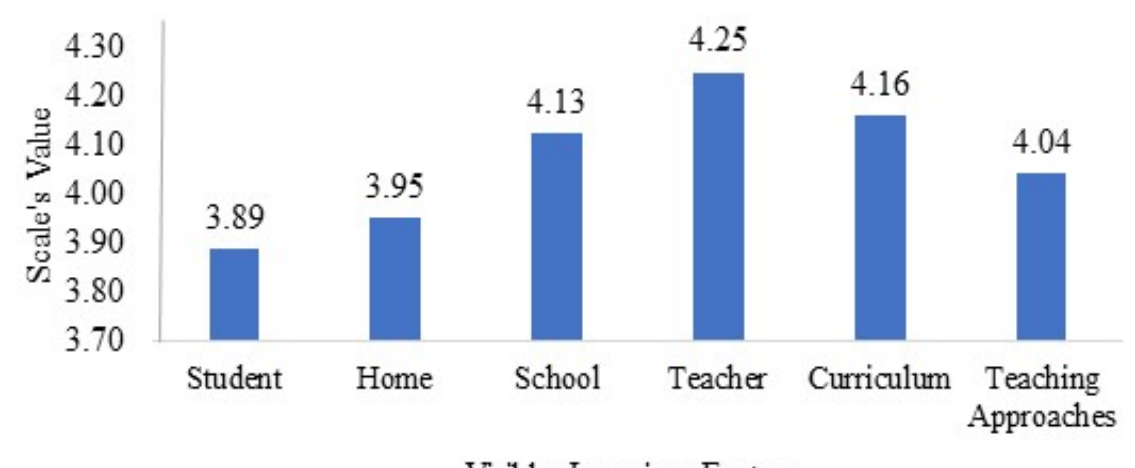

Visible Learning Factors

Figure 1. The implementation of visible learning is analysed from six factors

The implementation of visible learning that has been carried out is assessed by determining a scale value of 0 to 5, namely the categories are not good, not good, good enough, sound, and very good. The results showed that the implementation of visible learning was on a 4,0 scale or outstanding category with an analysis of 4 (four) factors or variables. Meanwhile, the other 2 (two) variables were categorised as exemplary implementation. To provide an overview of the implementation scale's value, a comparison between variables is shown in Figure 1.

Figure 1 shows the value of the implementation scale that stands out the most are the teacher (4.25), the curriculum (4.16), the school environment (4.13), and the teaching approach (4.04) with an outstanding category. Then the Home Environment variable (3.95) and Students (3.89) are in a suitable type. The conclusion that can be made is that the implementation of visible learning in elementary and junior high school students has been implemented well.

Based on the research results, the implementation of visible learning in students in schools can be seen from the following factors: child factors as students, home environmental factors, school environmental factors, teacher/educator factors, curriculum factors, and teaching approach factors. The practical implementation of visible learning was in the outstanding category with analysis of 4 (four) factors or variables. Each of these variables is teacher factors, curriculum factors, and teaching approach factors. Simultaneously, the other two variables with good implementation categories are home environmental factors and student factors (McKnight \& Whitburn, 2020).

Implementation of visible learning for students in schools with the highest scale, namely the teacher variable. The implementation assessment in this study shows that the teacher has implemented their duties very well in carrying out the learning process, both from selecting learning methods, conducting assessments that encourage students to learn independently, to giving praise and punishment to students. The second highest implementation is the curriculum variable. This curriculum variable shows that the teacher has developed essential competencies by paying attention to its breadth and depth. Besides, the implementation of curriculum activities has focused on developing meaningful learning strategies. Implementation with the following outstanding category is the school environment variable. The school environment is seen from 
creating a safe classroom climate, attention and a school environment that supports learning activities. A following variable is a teaching approach seen from the learning process that is goal-oriented and the success criteria, challenging tasks and providing feedback information about students' success. (Donohoo et al., 2018; Mezi $\&$ Dewantara, 2020).

The implementation of visible learning variables is categorised as either consisting of the home environment and student variables. The home environment that is seen is in the form of parents 'hopes and aspirations for their children and parents' knowledge about the school's vision. The last variable is students who are seen from students' previous knowledge about learning, expectations from learning, the relevance of subject matter with everyday life, and the willingness and ability to be involved in learning. The conclusion drawn from the research results is that the implementation of visible learning in primary education students has been implemented well. (Blyth \& Hunter, 2017).

\section{Relationship Between Variables of Visible Learning Implementation}

The relationship between visible learning variables illustrates that the variables have a relationship with each other as a unit. The relationship between these variables is shown in Table 2 as follows.

Table 2. Correlation between visible learning variables

\begin{tabular}{ccccccc}
\hline Variable & Student & $\begin{array}{c}\text { Home } \\
\text { environment }\end{array}$ & $\begin{array}{c}\text { School } \\
\text { environment }\end{array}$ & Teacher Curriculum & $\begin{array}{c}\text { Teaching } \\
\text { Approach }\end{array}$ \\
\hline Student & 1 & 0.709 & 0.405 & 0.484 & 0.551 & 0.470 \\
\hline $\begin{array}{c}\text { Home } \\
\text { environment }\end{array}$ & 0.709 & 1 & 0.543 & 0.540 & 0.519 & 0.616 \\
$\begin{array}{c}\text { School } \\
\text { environment }\end{array}$ & 0.405 & 0.543 & 1 & 0.742 & 0.637 & 0.502 \\
\hline Teacher & 0.484 & 0.540 & 0.742 & 1 & 0.808 & 0.652 \\
\hline Curriculum & 0.551 & 0.519 & 0.637 & 0.808 & 1 & 0.690 \\
\hline $\begin{array}{c}\text { Teaching } \\
\text { Approach }\end{array}$ & 0.470 & 0.616 & 0.502 & 0.652 & 0.690 & 1 \\
\hline
\end{tabular}

Based on table 2, it can be seen that the relationship between variables in the implementation of visible learning in schools. Regarding the number of coefficients and the sign $(+/-)$ of the correlation number, if a correlation number above 0.5 shows a strong enough correlation between variables and vice versa, the correlation is below 0.5 correlation. The positive $\operatorname{sign}(+)$ indicates the positive relationship between variables, while the negative number (-) shows the direction of the relationship between the negative variables. The visible learning variables' overall relationship showed signs that the visible learning implementation variables studied had a positive relationship.

The degree of relationship between visible learning variables is shown in two close categories. The relationship between variables is significant in a positive direction with a weak closeness, namely the relationship between 
students' factors and the school environment $(+0.405)$, the relationship between students and teachers $(+0.484)$, the relationship between students and the teaching approach $(+0.470)$.

The degree of the relationship between visible learning variables was proven to be significant towards a positive relationship and intense relationship closeness, namely the relationship between Student and Home Environment factors (positive 0.709), Student and Curriculum factors (positive 0.551), Teacher and Home Environment factors (positive 0.540), Teacher factors and curriculum (positive 0.808), Teacher factors and teaching approaches (positive 0.653), Curriculum and School Environment factors (positive 0.519), Curriculum and Teaching Approach factors (positive 0.690), Teaching approach factors and the home environment (positive 0.616), and the teaching approach factor and students (positive 0.502).

The relationship between variables in the implementation of visible learning in schools shows a positive relationship. This positive relationship indicates that the overall relationship between visible learning variables leads to a strong and mutually supportive relationship. Meanwhile, the closeness of the relationship between visible learning variables is shown in two closeness categories: intense familiarity and weak intimacy. The relationship between positive variables with a weak similarity between student factors and the school environment, students and teachers, students with a teaching approach (Dewitt, 2018; Terhart, 2011).

Then for the variables towards a positive relationship and intense closeness, namely the relationship between Student and Home Environment factors, Student and Curriculum factors, Teacher and Home Environment factors, Teacher factors and curriculum, Teacher factors and teaching approaches, Curriculum and
School Environment factors, factors Curriculum and Teaching Approach factors Teaching course and home environment, as well as teaching approach factors and students (Larsen, 2019; Nurgiansah et al., 2020).

In visible learning, it can be understood that there are relationships that work as a learning system. Variables as learning components have a connection between members and work to support each other. For example, a strong relationship between two variables indicates that when one variable has increased, the other variables will increase depending on the relationship's positive and weak value. In this study, the relationship between student variables and the home environment has a strong and positive relationship, meaning that when there is an increase in student variables, it will be followed by the rise in home environment variables, as well as between other variables that have a solid and positive relationship such as the Student factor variable. And Curriculum, Teacher and Home Environment factors, Teacher and curriculum factors, Teacher factors and teaching approaches, Curriculum and School Environment factors, Curriculum and Teaching Approach factors Teaching course and home environment, as well as teaching approach factors and students (Atmaja et al., 2020; Knight, 2019).

It is different when the variable has a positive but weak relationship; when there is an increase in the variable, other variables with a positive relationship will slightly increase. In this case, the relationship between student variables and the school environment has a positive relationship but has a weak closeness, meaning that when there is an increase in student variables, there will be a slight increase in the school environment variable, likewise with the relationship between variables that have a positive relationship but weak closeness, such as 
variables between students and teachers, and students with a teaching approach (Penuel et al., 2011; Terhart, 2011).

This study's relationship between variables shows that the variables as visible learning factors are a single unit or a mutually functional system; as said by Personal, learning as a system has interdependent, synergistic, dynamic, and cybernetic characteristics. Each component has a dependence on the other to achieve overall success. The performance of each element will result in optimal performance if each aspect supports the other. In a working system, each member must have a dynamic match. Each component of the system will communicate about each other efficiently. In visible learning, it can be understood that relationships work together as a learning system. Variables as learning components have a connection between members and work to support each other. Such a strong relationship between two variables indicates that the other variables will increase when one variable has increased.

\section{The Importance of Visible Learning}

The analysis of the importance of the six factors or variables supporting visible learning aims to understand these factors' importance in realising visual learning. The analysis results prove that the volume of visible learning elements has a scale value above 4.0 or an essential category. The learning interest category is divided into five categories from not important, less important, quite important, necessary and significant. Then, to describe the value of visible learning factors' importance scale, a comparison between variables is shown in Figure 2 below.

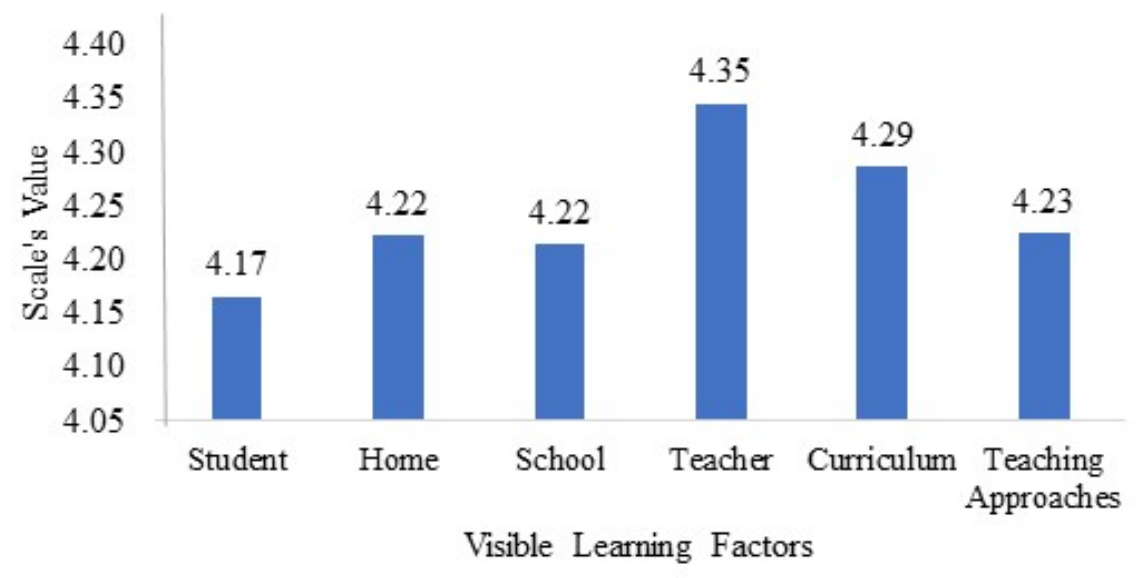

Figure 2. Value scale of interest of visible learning factors

Based on Figure 2, the value of the importance scale for visible learning factors shows a value $>4.0$ or all of which are very important. The conclusion that can be made is that the importance of visual learning factors to students is vital for teachers in primary education schools.

\section{Strengthening Visible learning}

Analysis to answer the strengthening of visible learning through t-test and analysis of implementation diagrams and the importance of visible learning factors. The following table presents a paired sample test to see the 
relationship between implementation and the importance of the visible learning variables.

Tabel 3. Paired samples test

\begin{tabular}{ccccccc}
\hline $\begin{array}{c}\text { Pair } \\
\text { (Implementation } \\
\text { and mportance) }\end{array}$ & Mean & $\begin{array}{c}\text { Std. } \\
\text { Deviation }\end{array}$ & $\begin{array}{c}\text { Std. Eror } \\
\text { Mean }\end{array}$ & t & df & $\begin{array}{c}\text { Sig. (2- } \\
\text { tailed) }\end{array}$ \\
\hline Student - Student & 2.80000 & 6.02715 & 0.85237 & 3.285 & 49 & 0.002 \\
\hline Home - Home & 1.64000 & 5.16566 & 0.73054 & 2.245 & 49 & 0.029 \\
\hline School - School & 0.36000 & 2.88387 & 0.40784 & 0.883 & 49 & 0.382 \\
\hline Teacher - Teacher & 1.64000 & 7.45260 & 1.05396 & 1.556 & 49 & 0.126 \\
\hline $\begin{array}{c}\text { Curriculum - } \\
\text { Curriculum }\end{array}$ & 0.38000 & 1.56349 & 0.22111 & 1.719 & 49 & 0.092 \\
\hline Teaching - Teaching & 1.46000 & 4.06182 & 0.57443 & 2.542 & 49 & 0.014 \\
\hline
\end{tabular}

Based on Table 3, the decision is taken based on the comparison of the calculated $t$ value and the statistical value of the t table. The value of t table at a significance level of 0.05 and with a df value or 49 degrees of freedom is 2.009575 . If the $t$-count value is greater than $t$-table, it is important to strengthen the visible learning factor. Based on table 3, it can be said that the strengthening of visible learning factors is important, namely the student factor because the statistical value of t count is greater than the value of t table, which is $3.285>2.009575$. Then the home environment factor with a statistical t-count value greater than the t-table value, namely 2.245 $>2.009575$, and the teaching strategy factor with a statistical t-count value of 2.542 which is greater than the t-table value of 2.009575. The strengthening of school environmental factors, teacher factors, and curriculum factors is not important or the level of importance is less to be given reinforcement because the value of the $t-$ count statistic is smaller than the value of t-table.

Therefore, the visible learning factors that need strengthening are student factors, homes and learning approaches. This can be concluded because there is a very large disparity between the implementation that has been carried out and the response to its interests. As presented in Figure 3. Analysis of the reinforcement diagram as follows.

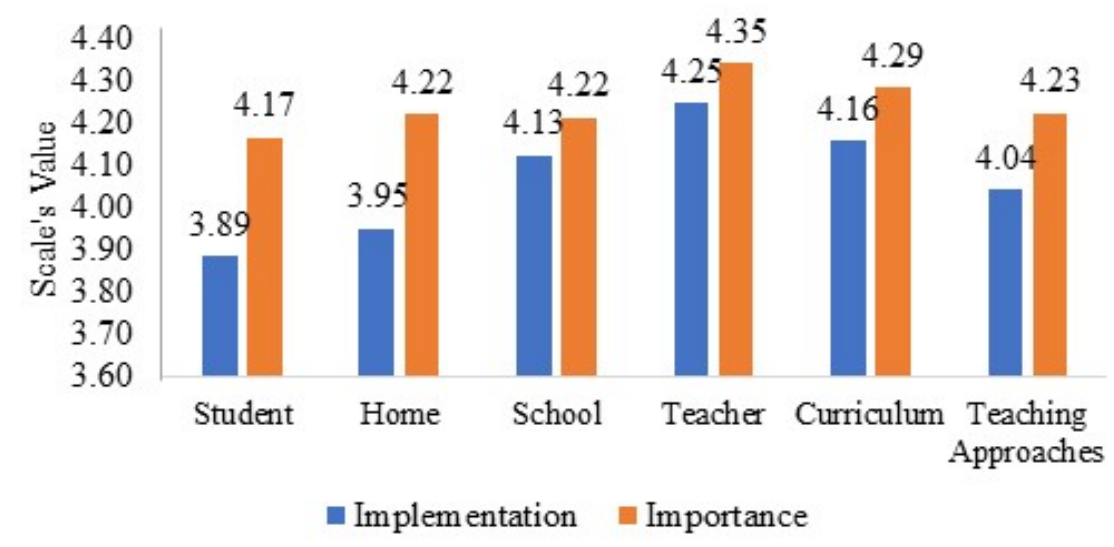

Figure 3. Implementation and importance of strengthening visible learning factors 
Based on Figure 3, it can be seen that the learning factors between implementation and strengthening interests that look identical are school environmental factors, teacher factors and curriculum factors. In comparison, the factors that appear to be imbalanced are student factors, home environmental factors, and teaching approach factors. Therefore, the factors that have imbalances between implementation and interests need to be strengthened to maximise visible learning.

Based on the research results, several factors require strengthening or actions that need to be further enhanced from implementing visible learning. These factors are in the form of student factors, home environmental factors, and teaching approach factors. Therefore, these factors have imbalances between implementation and interests, so it is necessary to strengthen them.

Estes emphasises that strengthening is a performance variable (performance) regarding strengthening the visible learning factor.(Hattie \& Zierer, 2019; Sharp et al., 2016). Estes further emphasises the cybernetics model for the effect of seasoning on the account. Cybernetics means a system that is automatically guided by feedback from the environment. Therefore, maintaining visible learning should start with the influence of teacher factors and school environmental factors. Strengthening learning begins with teachers and schools' efforts to enhance student performance, parents' role at home, and innovative teaching approaches. Teaching approaches that make it possible to impact students' visible learning performance include applying problem-based teaching that is contextual and meaningful (Dewitt, 2018; Rømer, 2019).

Strengthening home environmental factors can be done with parents paying more attention to students when studying at home by controlling children doing homework or by giving time limits to play online games. Besides, parents provide adequate and conducive facilities by creating a calm learning atmosphere. Parents must also know the school's vision and mission to establish good cooperation between parents of students and teachers.

Strengthening the teaching factor can be done by providing feedback or feedback from teachers to students or teachers. Improved feedback activities make a significant contribution to making visible learning a reality. Benson stated that students who provide feedback to the teacher during learning become more proactive and develop more rapidly than students who do not provide feedback. Therefore, improving visible education from the teaching factor includes input from both the teacher to the students and the students to the teacher because it can motivate students (Fisher et al., 2016; McKnight \& Whitburn, 2020).

The teacher is an essential component in learning. The ability of teachers to operate technology also makes a significant contribution. Al-Abdullatif and Alsaeed found that teachers' ICT competence affects the quality of their education. The teacher realises that mastery of ICT, subject matter and teaching techniques must be improved to be applied in classroom learning. Then from the teacher's competence, it can be seen from the learning activities and positively related students' progress.

In essence, visible learning is learning that has visible impacts, namely empowering education and continuous learning. Visual learning engages teachers and sees the effects of learning through students' attitudes and behaviour to better understand learning objectives as the key to their constant learning (Hattie et al., 2016; Knight, 2019). Strengthening visible learning looks at how to increase the impact of learning experienced by students. The strengthening that is carried out is expected to maximise changes in students' learning process, attitudes, and behaviour in participating in learning activities in class. As John Hattie meant that visible learning sees learning 
objectives as challenging and explicit, and honest, one way for clear knowledge is to formulate learning objectives to memorise or learn something by providing opportunities to compete. As Anderson said, learning objectives are a practical part of changing students' educational process (Anderson \& Krathwohl, 2010; Hattie, 2012).

\section{CONCLUSIONS}

This study's conclusions are as follows: The implementation of visible learning factors for elementary and junior high school students has been implemented well and very well. The relationship between visual learning factors as a whole is significant in a positive direction with a strong, weak relationship including student factors and the school environment, the relationship between students and teachers, the relationship between students and the teaching approach. The relationship between the variables of visible learning factors is proven to be significant in the direction of a positive relationship and the closeness of a strong relationship, namely the relationship between Student and Home Environment factors, Student and Curriculum factors, Teacher and Home Environment factors, Teacher and curriculum factors, Teacher factors and teaching approaches, Curriculum and School Environment factors, Curriculum and Teaching Approach factors, teaching approach factors and home environment, and teaching approach factors and students. The importance of visible learning factors all has a scale value above 4.0 or an essential category. Some of the learning factors visible from the implementation and the interests of strengthening that seem identical are the school environment factor, the teacher factor and the curriculum factor. Meanwhile, the factors that can be seen that there are imbalances that require strengthening are students' factors, home environmental factors, and teaching approach factors.
This research on data collection was conducted on teacher respondents. Meanwhile, visible learning should be felt by the students and parents of the students concerned. Comprehensive data collection is essential to reveal the visual learning performance of students. Therefore, future research needs to involve many participants as sources of data from all visible learning stakeholders for students. Strengthening learning starts with teachers and schools' efforts to strengthen student performance, parents' role at home, and efforts to innovate teaching approaches. A teaching approach that impacts students' visible learning performance is problembased teaching that is contextual and meaningful.

\section{REFERENCES}

Anderson, L., \& Krathwohl, D. (2010). Pembelajaran, pengajaran, dan assesment. [Learning, teaching, and assessment]. Yogyakarta: Pustaka Pelajar. Atmaja, T. S., Dewantara, J. A., \& Utomo, B. B. (2020). Penguatan pendidikan karakter berbasis sekolah menengah atas perbatasan entikong kalimantan barat [Strengthening character education based on entikong border high school, west kalimantan]. Jurnal Basicedu, 4(4), 1257-1266.

Blyth, N. \& Hunter, D. (2017). Improving teacher clarity/: enacting visible learning theory into action. Penrhos College

Dewitt, P. (2018). Using visible learning research to influence collaborative leadership. Education Sciences, 8(4). 219, 1-9

Donohoo, J., Bryen, S., \& Weishar, B. (2018). Implementing high-leverage influences from the visible learning synthesis: Six supporting conditions. Education Sciences, 8(4). 215, 1-12

Fisher, D., Frey, N., \& Hattie, J. (2016). Visible learning for literacy: implementing the 
practices that work best to accelerate student learning grades $k$-12. California: Corwin Literacy.

Hattie, J. (2008). Invisible learning: a synthesis of over 800 meta-analyses relating to achievement. New York: Routledge

Hattie, J. (2012). Visible learning for teachers: maximising impact on learning. London and New York: Routledge.

Hattie, J., Masters, D., \& Birch, K. (2016). Visible learning into action: international case studies of impact. New York: Routledge.

Hattie, J., \& Zierer, K. (2019). Visible learning insights. London and New York: Routledge.

Ivan, S., John, O., John, C., O’neill, A. M., \& Roger, O. (2009). Commentary invisible learnings? a commentary on john hattie's book: visible learning: a synthesis of over 800 meta-analyses relating to achievement. New Zealand Journal of Educational Studies, 44(1), 93-106.

Knight, J. (2019). Instructional coaching for implementing visible learning: a model for translating research into practice. Education Sciences, 9(2). 101, 1-16

Larsen, S. N. (2019). Blindness in seeing: a philosophical critique of the visual learning paradigm in education. Education Sciences, 9(1), 47, 1-12.

Lopez-Fernandez, O., \& Molina-Azorín, J. F. (2011). The use of mixed methods research in interdisciplinary educational journals. International Journal of Multiple Research Approaches, 5(2), 269-283.

McKnight, L., \& Whitburn, B. (2020). Seven reasons to question the sovereignty of Visible Learning. Discourse, 41(1), 3244.

Mezi, M., \& Dewantara, J. A. (2020). Implementation of character education in the student council. Jurnal Basicedu, 4(3), 765-774.

Molina-Azorin, J. F. (2016). Mixed methods research: an opportunity to improve our studies and our research skills. European Journal of Management and Business Economics, 25(2), 37-38.

Nurgiansah, T. H., Dewantara, A., \& Rachman, F. (2020). The implementation of character education in the civics education syllabus at sma negeri 1 sleman. JED (Journal of Etika Demokrasi), 5(2), 110-121.

Penuel, W. R., Fishman, B. J., Cheng, B., \& Sabelli, N. (2011). Organising research and development at the intersection of learning, implementation, and design. Educational Researcher, 40(7), 331-337.

Qvortrup, L. (2019). Visible learning and its enemies-the missing link. Nordic Journal of Studies in Educational Policy, 5(1), $1-5$.

Raiyn, J. (2016). The role of visual learning in improving students' high-order thinking skills. Journal of Education and Practice, 7(24), 115-121. http:// files.eric.ed.gov/fulltext/EJ1112894.pdf

Rømer, T.A. (2019). A critique of john hattie's theory of visible learning. Educational Philosophy and Theory, 51(6), 587-598. Sharp, L., Dougherty, J., Baca, G., \& DiegoMedrano, E. (2016). The implementation of visible learning practices among refugee learners in north-west texas. Diversity, Social Justice, and the Educational Leader, 1(2), 26-39

Terhart, E. (2011). Has john hattie found the holy grail of research on teaching? an extended review of visible learning. Journal of Curriculum Studies, 43(3), 425-438. 
